\title{
Democratic Administration Value in Practice-On the Development and Effect of the School of Thoughts of New Public Administration
}

\author{
Dongmei $\mathrm{Li}^{1,2}$ \\ ${ }^{1}$ School of Public Affairs, Xiamen University, Xiamen Fujian, 361005, China \\ ${ }^{2}$ Kunming University, Kunming Yunnan, 650214, China
}

\begin{abstract}
Keywords: Democratic Administration Value, New Public Administration, Commonality, Bureaucracy
\end{abstract}

\begin{abstract}
Democratic administration value is the main idea of the school of thoughts of new public administration. This article has analyzed the mutual effect and mutual penetration of democratic administration value and western public administration thought on and into each other through presenting the main content of democratic administration value: social equity concept, commonality of public administrators and in combination with the development and change of the school of thoughts of new public administration in recent years; and drawn a conclusion that democratic administration value is an essential and indispensable value idea in public administration in future, and has a great value of reference to the thoughts and practice of public administration of China.
\end{abstract}

\section{Question Introduction}

The period of the 1960s was called "a time of turbulence" by D.Waldo. The political environment intensified the distrust in the government in the traditional thinking of American, and the society started challenging the political system. As pointed out by O.C.Mcswhite, "actually the attempt to defend general social science, political science and especially some influential academic traditions in public administration has become less indefatigable." In 1968, Waldo convened the first Minnowbrook Conference in the Minnowbrook Conferences Center of the Syracuse University, to discuss and reflect on the problems and challenges faced by public administration. This conference marked the birth of the theory and the school of thoughts of new public administration, and the return of "political value" in modern public administration thoughts. According to Waldo, "different from the research tendency of traditional positivism and scientism, the viewpoint of new public administration emphasizes norm theory (various proper value ideas), philosophical foundation (existentialism and phenomenology), social care and social action."

Fredricksen, another representative personage of new public administration, published a paper on the Founders' Forum of the ASPA in March 2009, pointing out that "Minnowbrook is an eternal legend, a mysterious and mythological narration in the field of public administration. The Minnowbrook Conference which was held every 20 years $(1968,1988,2008)$ in the Minnowbrook Conferences Center of the Syracuse University is a cicada in the field of public administrationappears once every 20 years, creates a situation, and hides within soil for rest and preparing for the next appearance. This is true for the scholars of public administration of every generation, all of who have their own Minnobrooks." As he put it, the mainstream comment on the school of thoughts of new public administration in the academic circle was that "it is the most active school of thoughts in the public administration circle in America since the 1970s", and the situation created by it has affected and permeated into the Blacksburg School, the Public Administration Theory Network, the new public administration theory, and the new public service thought; in turn, the development of other thoughts also affects the constant evolution of the thought of democratic administration. According to The Blackwell Encyclopedia of Political Science, "new public administration is not coherent in concept, has no clearly defined constitutional basis, and fails to take root. Thus it is liable to be just regarded as an emotional outburst by the discommenders, and then ignored." In deed, no influential schools and thoughts of new public administration has been developed and formed in western administration thought history, for new public administration focuses on criterion research 
and is thought to be an unrealizable idea. Throughout the development of public administration, however, the democratic public administration idea has made ineffaceable contributions to the development of western public administration.

This article has analyzed the mutual effect and permeation of the school of new public administration and the thoughts and practice of western public administration on and into each other through explaining the main ideas of the democratic administration idea and its development and changes, with a hope to explore the reference value of the democratic administration idea for the development of China's sublic administration.

\section{Main Thoughts of Democratic Administration Idea}

Although the themes of the Minnobrook Conferences in the past 60 years were not the same, the main thoughts of the democratic administration idea has been emphasized repeatedly - construct a new organization system or institution emphasizing ethics, democracy, political interaction, civic participation and responsiveness, and other administrative actions, to accelerate the coming of social equity.

One of the focal point for realizing the democratic administration idea is the role of government officials in protecting and promoting democracy through the adoption of democracy at work. This idea points out the significance of public administrators in the realization of the democratic administration idea. Furthermore, the demonstration emphasizing that officials should improve public service quality via conscious efforts and building a good public service image in modern public administration also indicates the link role of public administrators in democratic administration. According to the democratic administration idea, officials are expected to become representative citizens (representative), and fulfill the commitment of social equity of public administrators via the possession of legal personal authority and system authority for administering the state and complying with the law; adhering to the democratic administration idea, public administrators will be responsible (responsiveness) for citizens; such commitment and responsiveness will manifest the spirit of public administration finally.

\section{Mutual Permeation between Democratic Administration Idea and Western Public Administration Thoughts}

According to the democratic administration, it is expected to realize social equity through ethics, democracy, political reaction, civic participation and responsiveness. Through comparing the three Minnobrook Conferences, it is found that the development of new public administration has been constantly adapting itself to the changes of the public administration environment. Meanwhile, in the era of contention of schools of thoughts, the democratic administration idea also has been being affected and challenged by other thoughts. As put by Dr. Jong S. Jun, traditional public administration activities were limited to internal management of organization, which has ignored the "commonality" of public administration, and not emphasized the extension of the potentials of its members either $\cdots \cdots$, while the new public administration can be regarded as a "changeful administration pattern", of which the form will change with the change of situation in uncertain future.

\section{Democratic Administration Idea and Traditional Administration Thoughts}

In the new public administration thought, traditional public administration theories have not be completely denied. As put by Waldo, the school of new public administration do not think that equity and efficiency are absolutely incompatible. In the democratic administration idea, the overdependence of traditional public administration on the positivism is questioned, and that the traditional public administration emphasizes its internal management and ignores the spiritual value is criticized. Thus, the democratic administration value which places more emphasis on the feature of commonality of public administration, and social equity, participation, responsiveness and sense of 
social responsibility is resorted to. Waldo also had put forward the concept of "social efficiency" to distinguish from the "technical efficiency" advocated in traditional administration thoughts.

\section{Realization of Social equity in Democratic Administration}

People' s sense of pursuing "kindness" and "happiness" has been constructed long time ago. With the maturity of the subject, the science of public administration has been separated from the political science. In order to consolidate the independence, a view of politics-administration dichotomy has been put forward in the administration thought, and the return of "political value" has been put forward in the administration thoughts to distinguish from the management science, while the science of public administration is not sure to stick to which one of "political value" and "management value". However, the final direction of the value pendulum of public administration is decided by the particular situation like the pendulum constructed by Herbert Kaufmann.

\section{Role of Government in Democratic Administration}

In the new public administration science, it is advocated to enhance the role of government in democratic administration, which is reflected by the link role of public administrators in democratic administration and the support to civic participation. According to the new public administration science, the government has a navigation function in the realization of "commonality" and "efficiency", and it is expected to realize the "commonality" of the society via the public spirit of public administrators under the bureaucracy. Civic participation is advocated. In addition, the concept of citizen in modern public administration has been explicitly distinguished from the concept of "all people as the sovereignty" held in traditional public administration. However, the aim is to develop the patriotism of being ready to do charity of citizens, and facilitate citizens understanding public administration and seeking the legal source of administration. Thus, the so-called participation role is different from the actual role of citizens in the governance under the social construction theory. The viewpoint of enhancing the role of the government in the democratic administration idea has been criticized, especially the civic participation theory, which has been surpassed by that of other schools of thoughts, including the school of new public administration, the school of governance, etc. One of the reasons is that the administration based on authority division in administration practice has provided more opportunities and examples for civic participation. However, it is widely believed in the academic circle that the existence of government is necessary, because there is indeed some fields that civic participation is unable to intervene, and the judgment that acknowledges the value of public administrators in the government indeed is affecting public administration actions. At the third Minnobrook Conference held in 2008, the role of government in social governance has been pointed out once again in face of the issue of international terrorism.

\section{Democratic Administration and Public Administration around the World}

At the third Minnobrook Conference themed by "The future of public administration, public management, and public service around the world" (2008), the importance of comparative study on public administration has been pointed out once again in face of the situation where the interdependence degree of countries around the world gets increasingly high, and the global issues become more and more acute, including resources, environment, population, transnational crime, international security, etc., and it was appealed to pay attention to global public administration. It is worth mentioning that among the attendees of the Conference, 13 attendees were from countries other than the United States, including scholars from China, South Korea, Brazil and Thailand. At the Conference, seminars among the group of discussion on public service around the world has been held. Some scholars believed that the Minnobrook Conference to be held in 2028 would change from the Minnobrook of America into the Minnobrook of the world. The focus of attention to public administration has been gradually turned into that to the public administration around the world. 


\section{Conclusion}

Thomas S.Kuhn pointed out in the Structure of Scientific Revolutions in 1962 that a scientific normal form was a set of systematic hypothesis about the reality. Such set of hypothesis mainly included the rules for explaining and interpreting a certain type of realities, and the aforementioned rules were reflected by people' s viewpoints, concepts and basic value judgment criterion in observing the real world. Whether a normal form was good or not could be determined from whether the hypotheses therein had completely and accurately reflected the real world. In order to explain the reality of public administration, scholars spare no efforts to think and make breakthroughs. Every breakthrough were the results obtained via absorptive comprehension and critical reflection. The commonality, social equity, participation and responsiveness advocated in the democratic administration idea have truly affected and have been affecting the administration actions of governments of countries around the world.

As we know, the existence of government is necessary in social governance. Besides, as pointed out in the third Minnobrook Conference, as more and more global issues rise, the role of government will become irreplaceable in solving these complicated social issues. Of course, it is impossible to realize happiness of all mankind by constructing the order of the whole society solely by government under current situation, because there are unsolvable social issues in the existing institutional and functional public administration system. In every decision of government, whether domestic or international public administration issues, the government must take account of the democratic administration idea, and both public administrators (including the "invisible bureaucrats" mentioned by Fredricksen) and citizens must consider the "public spirit". On the other hand, as introduced by Fredricksen in The Spirit of Public Administration, the democratic administration idea is irreplaceable in respect of the guarantee for the interests of the minority ethnic groups and the disadvantaged groups, and social equity indeed should be realized via "commonality-oriented" distribution based on government decision.

The science of new public administration is a theory developing in the west, where the public administration system is relatively mature. Is the democratic administration idea applicable to the public administration environment of China? In my view, though new public administration and new public service is gradually becoming the mainstream direction of research in the public administration circle in China, the democratic administration idea advocated by the school of new public administration can be referred to for purpose of solving the issue of social equity of China.

\section{References}

[1] [Britain] David Miller, Vernon Bogdanor, DENG Zhenglai (Translator), The Blackwell Encyclopedia of Political Science, China University of Political Science and Law Press, 1992

[2] [America] Nicholas Henry, XIANG Long (Translator), Public Administration and Public Affairs, China Renmin University Press, 2002

[3] [America] George Fredricksen, ZHANG Chengfu et al (Translator), The Spirit of Public Administration, China Renmin University Press, 2003

[4] [America] Dr. Jong S. Jun, SUN Boying (Translator), The Social Construction of Public Administration: Interpretation and Critical Perspectives, Peking University Press, 2008

[5] [America] O.C.Mcswite, WU Qiong (Translator), Legimacy in Public Administration-A Discourse Analysis, China Renmin University Press, 2002

[6] TAN Gongrong, Schools of Thoughts of Public Administration in the West, Peking University Press, 2008

[7] CHEN Zhenming, From Public Administration, New Public Administration to Public Management-"Pattern" Change in the Research Field of Management of Western Governments, CASS Journal of Political Science, 1999, edition 1 
[8] [America] Cottney, Mark Holzer, ZHANG Mengzhong, New Public Administration: Seek Social Equity and Democracy, Chinese Public Administration, 2001, edition 2

[9] [America] Cottney, Mark Holzer, ZHANG Mengzhong, New Public Administration: Seek Social Equity and Democracy, Chinese Public Administration, 2001, edition 2

[10]ZHENG Gongcheng, Analysis of Social Equity Status of China, Journal of Renmin University of China, 2009, edition 2

[11]HUANG Yuanzhi, Waldo and New Public Administration Movement, Journal of Xiong School, Edition VIII, Nov. 1994

[12]SHANG Huping, "Governance Performance Management" Trend to Thrive-Predication Based on the Third Minnobrook Conference, Journal of Public Management, Jan. 2010, Volume VII, Edition I

[13]HU Xiaofang, Criticism and Defense: the Politics-administration Dichotomy in the Perspective of New Public Administration, journal of us-china public administration. 2006, vol3, no.4

[14]YUAN Zushe, Values and Beliefs of "Commonality" and Cultural Ideal thereof, Journal of Renmin University of China, 2007, edition 1

[15][America] George Fredricksen, Minnowbrook: Reflection and Observation, Administrative Tribune, 2010, edition 1

[16] [America] George Fredricksen, Comparison between Reinventing Government Movement and New Public Administration, ournal of Chinese Academy of Governance, 2001, edition 1 